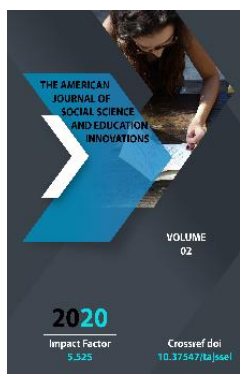

\title{
The Role Of Language Competence In The German Language
}

Kakhorova Zabarjad

Student, Karshi State University, Uzbekistan

Copyright: Original content from this work may be used under the terms of the creative commons attributes 4.0 licence.

\section{ABSTRACT}

This article focuses on the specific role language skills play in Language Learning, with an emphasis on the role of language skills in German and which is Conveyed to learners.

\section{KEYWORDS}

Language skills, Versperformance, Language rules, Language skills, Means of communication, Application, Language structure.

\section{INTRODUCTION}

What is language proficiency? Why do you need it ? Language competence is an important tool for learning Foreign languages. This is how we develop language skills. Build language skills the Ability to speak, read, hear and write in the language we are learning. Diesis an important aid in Mastering the toolearning language. Today the world is inall areas rely on innovative technologies. Insspecial is the study of Foreign languages dealt with. First we need the components of language proficiencyexamine. It doesn't matter what language we learn. Every foreign language learned hastheir own rules and skills. This is particularly reflected in the German language again. Language skills include "comprehension" (listening and reading comprehension) and Knowledge performance in the sense of "vocabulary and 
grammar". The performance mentioned pointthe language skills of the German learners. It's amazing despite the learner hardly communicate with a good knowledge of German and do not achieve the expected success can. But the students practice, hear a lot, read aloud and memorize texts is important so that the learner gets to grips with the Foreign language structure as quickly andcan familiarize you intensively. The learners have to learn with the help of the receptionist Linguistic rules creatively generate your own linguistic utterances byie, sentences in Reading text around shapes, rewrite and summarize texts. Ideally have the Learners a German environment that enables them to speak their German with native speakers to Train.

\section{RESULT AND DISCUSSION}

I would also like to noc my friends with this posth the following didaktic suggestions to raise awareness of skills development with: 1 . Resetting the learning objective: What is the subject of the language teaching? D.as textbook or the Person as a learner? This question must be asked before devising a languagechkurses answered will. In order to teach successfully, the core task of developing skills is ato grasp. ItThis is about the focal point of education: key qualifications Decoration. After Zhong is consecratedthe teaching "as the Platform for competence building and Quallocation of professionals too conceive. "It is therefore more important for us to know what is learningnd in class than what we mucked up hBut in this seemingly low However, the differentiated formulation hides a major underscorechied in terms of new Perspektiven: If we sta focus on ourselves on die learners must we always strive to bring them to the learning goal. 2. Language teaching as a dynamic process: The DaF lessons is not supposed to be a statische Language mediation, but as a dynamic learning process gestAccording to Lako and Johnson, language proficiency is the product of perceptionung and des Experience.Perception and experience happen in everyday life communication. One does learna foreign language is best avoided using it - what one has experienced, understands one is much better and language is created from acquired language skills competence. 3. Learner-centered GFL teaching: You should only hear the sums of the teacher, sollten more "Voice" Have a say in the classroom, ie the participation of the learners in the Unteaching is essential. TheTeacher unites the funcons of an actor and a director, so to speak. When Actors should make his teaching material lively and interestingto graze. As a director he should Put all learners in the role in which they understand the subject matterfully absorb and can process. Lively interacation between teachers and studentsends in DaF-Lessons promise great learning success. The teaching material, however, applies in teaching only as a factor in success, not the only onege. The teacher shouldn't just pay attention to it focus on the teaching material but also on the learners. 4 .Introduce training hours into GFL teaching: speaking is a Ghabitation. To the learnerGetting used to a foreign language structure are training hours m.- E. Essential. Ifbut for reasons. The lack of time in the teaching workload no timet, the teacher should do the At least show learners ways of doing Tcan rain. Mixing up methods enables learners to be autonomousen learning.

\section{CONCLUSION}


One might think that the task is to give the learner language skillsconvey. In my opinion, however, you have to do a lot more and the learnersenable them to Apply what they have learned. "Man is a social being and theLanguage is primarily used for communication in a society ". For the successful DaF-Learning / Teaching you have to put yourself in a real situation and German whenBe able to use means of communication. Knowledge is not enough, it comesrather, it should be applied correctly and appropriately. Only then can we our Reach a target.

\section{REFERENCES}

1. The law ". Decision on measures to further improve theForeign language learning system ", PQ-1875-Number. 2012.

2. A guide to studying language proficiency.

3. "Tangram" currently 2 by Rosa Maria Dallapiaza. 2013. 27p

4. "Tangram" currently 3 by Eduard from Jan. 2013. 38p 5. The law "Decision on measures to further improve the Foreign Language learning System", PQ-1875, T. 2019. 